in the need for these prophylactic measures is urgently necessary and overdue.

We are grateful to Dr. S. Haase for radiological assistance, and to the Dietetic Department, Stobhill Hospital, for help with the diet histories. We are also indebted to Mr. F. M. Sharif, President of the Glasgow Pakistani Social and Cultural Society, through whom the survey was arranged, and to the families themselves for their willing participation. Professor J. H. Hutchison, Royal Hospital for Sick Children, Glasgow, and Mr. A. McDougall, Victoria Infirmary, Glasgow, kindly allowed us access to the case records of rachitic patients under their care.

\section{References}

Albright, F., Burnett, C. H., Parson, W., Reifenstein, E. C., and Roos, A. (1946). Medicine, 25, 399.

Arneil, G. C., and Crosbie, J. C. (1963). Lancet, 2, 423.

Benson, P. F., Stroud, C. E., Mitchell, N. J., and Nicolaides, A. (1963).

British Medical fournal, i, 1054.

Bransby, E. R., and Fothergill, J. E. (1954). British fournal of Nutrition, 8 ,
Dunnigan, M. G., et al. (1962). Scottish Medical Fournal, 7, 159.

Dunnigan, M. G., and Gardner, M. D. (1965). Scottish Medical fournal, 10, 325.

Dunnigan, M. G., and Smith, C. M. (1965). Scottish Medical fournal, 10,1. Felton, D. J. C., and Stone, W. D. (1966). British Medical Fournal, 1, 1521. Gray, C. H. (1965). Clinical Chemical Pathology, London, Arnold.

Greenberg, B. G., Winters, R. W., and Graham, J. B. (1960). fournal of Clinical Endocrinology and Metabolism, 20, 364.

Hunter, J., Maxwell, J. D., Stewart, J. D., Parsons, V., and Williams R. (1971). British Medical fournal, 4, 202.

Jonxis, J. H. P., Smith, P. A., and Huisman, T. H. J. (1952). Lancet, 2,

Loomis, W. F. (1967). Science, 157, 501.

Lumb, G. A., Mawer, E. B., and Stanbury, S. W. (1971). American fournal of Medicine, 50, 421.

Nordin, B. E. C., and Smith, D. A. (1965). Diagnostic Procedures in Disorders of Calcium Metabolism. London, Churchill.

Panel on Child Nutrition (1970). Reports on Public Health and Medical Subjects, No. 123. London, H.M.S.O.

Richards, I. D. G., et al. (1968a). Scottish Medical Fournal, 13, 297.

Richards, I. D. G., Sweet, E. M., and Arneil, G. C. (1968b). Lancet, 1, 803. Stroud, C. E. (1971). British fournal of Hospital Medicine, 5, 629.

Swan, C. H. J., and Cooke, W. T. (1971). Lancet, 2, 456.

Widdowson, E. M. (1947). Medical Research Council, Special Report Series. No. 257. London, H.M.S.O. Wills, M. R., Day, R. C., Phillips, J. B., and Bateman, E. C. (1972). Lancet,

\title{
Follow-up of Cases of Opiate Addiction from the Time of Notification to the Home Office
}

\section{Introduction}

A total of 108 cases of opiate* addiction were followed up for six to seven years until April 1971. The five-year follow-up from first contact with us was published elsewhere (Chapple et al., 1972), together with a method of staging according to the time since notification to the Home Office when first seen. Stage 1 or "early" addicts were defined as those seen within three months of initial notification, stage 2 or "pre-chronic" addicts three to 18 months, and stage 3 or "chronic" addicts those notified more than 18 months previously. The number of opiate-free patients after five years was shown to be significantly different for addicts at the three stages.

*Opiates for the purposes of this study include heroin, pethidine, morphine, methadone. Nevertheless, all but one of the 108 were using heroin when first seen by us.

National Addiction and Research Institute, London S.W.10

PETER A. L. CHAPPLE, M.B., D.P.M., Medical Director

DAVID E. SOMEKH, M.B., CH.B., Research Unit

MARILYN E. TAYLOR, B.A., Research Unit

\section{Patients}

All the patients were first seen by one of us (P.A.L.C.) between November 1963 and September 1965 inclusive. Twelve were seen at St. Giles' outpatient clinic, 31 at Lambeth outpatient clinic, 28 at Cane Hill Hospital (mostly as outpatients, a few as inpatients), 32 at West Park Hospital (similarly), and 5 as general practice patients. They later dispersed to several treatment situations. Some who remained with us were referred back to their general practitioner after discharge from hospital and jointly supervised either at the outpatient clinic or later at the National Addiction and Research Institute in Chelsea.

The status of each patient in April each year after their first contact with us was ascertained primarily from the Home Office

TABLE I-Age, Sex, and Country of Origin of Present Patients and of All New Patients in Great Britain during 1955-64. All Patients were Non-therapeutic Addicts

\begin{tabular}{|c|c|c|c|c|c|}
\hline & & \multirow{2}{*}{$\begin{array}{c}\text { 1955-64 } \\
\text { Sample } \\
(\%)\end{array}$} & \multirow{2}{*}{$\begin{array}{c}\text { Present } \\
\text { Patients } \\
(\%)\end{array}$} & \multicolumn{2}{|c|}{ Mean Age in Years } \\
\hline & & & & $\begin{array}{l}\text { 1955-64 } \\
\text { Sample }\end{array}$ & $\begin{array}{l}\text { Present } \\
\text { Patients }\end{array}$ \\
\hline $\begin{array}{l}\text { British origin } \\
\text { Non-British origin }\end{array}$ & $\begin{cases}\text { Men } & \cdots \\
\text { Women } & \cdots \\
\text { Men } & \cdots \\
\text { Women } & \cdots\end{cases}$ & $\begin{array}{r}54 \\
23 \\
20 \\
3\end{array}$ & $\begin{array}{r}61 \cdot 0 \\
24 \cdot 5 \\
12 \cdot 5 \\
2 \cdot 0\end{array}$ & $\begin{array}{l}24 \cdot 6 \\
21 \cdot 8 \\
31 \cdot 4 \\
30 \cdot 2\end{array}$ & $\begin{array}{l}23 \cdot 7 \\
21 \cdot 7 \\
31 \cdot 6 \\
32 \cdot 5\end{array}$ \\
\hline Total & $\left\{\begin{array}{l}\text { Men } \\
\text { Women }\end{array}\right.$ & $\begin{array}{l}74 \\
26\end{array}$ & $\begin{array}{l}73 \cdot 5 \\
26.5\end{array}$ & $\begin{array}{l}26 \cdot 4 \\
22 \cdot 3 \\
\end{array}$ & $\begin{array}{l}24 \cdot 5 \\
22.5 \\
\end{array}$ \\
\hline No. of patients $\ldots$ & .. & 436 & $105^{*}$ & & \\
\hline
\end{tabular}

*Three patients registered before 1955 are excluded.

TABLE II-Age of Sample compared with All Heroin Users in 1964 and 1965 in Great Britain. Figures given are Percentages

\begin{tabular}{|c|c|c|c|c|c|c|}
\hline \multicolumn{4}{|c|}{ Age (years) } & \multirow{2}{*}{$\begin{array}{l}1964 \\
12.5 \\
68.5 \\
19 \cdot 0\end{array}$} & \multirow{2}{*}{$\begin{array}{c}108 \text { Cases } \\
21 \cdot 5 \\
66.5 \\
12 \cdot 0\end{array}$} & \multirow{2}{*}{$\begin{array}{l}1965 \\
26.5 \\
63.0 \\
10.5\end{array}$} \\
\hline $\begin{array}{ll}\text { Under } & 20 \\
20-34 & \ldots \\
35-49 & \ldots\end{array}$ & $\begin{array}{l}\ldots \\
\cdots\end{array}$ & $\begin{array}{l}\because \\
\cdots\end{array}$ & $\begin{array}{l}\because \\
\cdots\end{array}$ & & & \\
\hline No. of pat & & .. & . & 320 & $106^{*}$ & 505 \\
\hline
\end{tabular}

* One patient aged 50 and a patient using pethidine were not included. 
Drugs Branch records. Any additional clinical information that we had helped to clarify their status, particularly when subjects had lapsed from notification in a given year. Clinical contact with patients (especially those designated as "off-drugs") was maintained for evaluation of life-style whenever possible.

We examined the characteristics of the sample by reference to Bewley's (1965) figures and those issued by the Home Office (Drugs Branch, Home Office, 1970). All the patients were of "non-therapeutic" origin, 107 were white, mean age at first contact was 26.0 years, and 79 were male. A comparison with all new patients notified during 1955-64 (Table I) shows a close similarity both in proportion of patients and in mean ages in the subgroups. A difference worth noting is that there were rather more young male British patients in the present sample, which is consistent with the fact that some of these patients were first notified in 1965. This is borne out by a comparison between all patients taking heroin in 1964 and 1965 and the present group (Table II). The comparison shows that by age the proportions in the present sample were exactly intermediate between those of 1964 and 1965. In fact, the modal month of contact for this series was November 1964. The approximation of the sample to a random sample is not surprising as our sample represents one-fifth of all known heroin addicts of non-therapeutic origin in the age range (up to 50 years) for 1965.

\section{Follow-up to Date}

It is a difficult task to record the changing status of drug addicts over a period of years in a meaningful way. The method we have chosen is to determine the addict's involvement with drugs at regularly-spaced intervals, aiming for a high degree of certainty. The status of 108 opiate users in April 1971 (representing a follow-up of six to seven years from first contact) is shown in Table III. The terms used need little explanation. Those

TABLE III-Status of the 108 Patients at Follow-up in April 1971

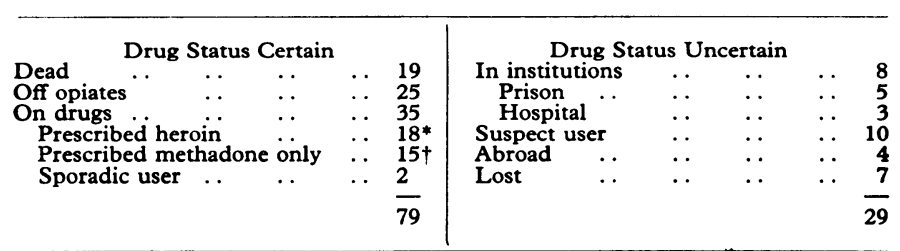

*Five at Charing Cross, 4 at St. Giles', 4 at St. George's, 2 at All Saints', 3 at other clinics.

designated as "suspect users" are patients who have lapsed from notification but whom from other evidence we strongly suspect to be obtaining illicit opiates. Two or three patients in each follow-up year fell into the "sporadic use" category-that is, where opiate use is known to be irregular or where there is regular abuse of other drugs, such as barbiturates, cyclopropane, and LSD, or where both conditions obtain.

After six to seven years 35 patients $(32 \%)$ were still being prescribed opiates and $19(18 \%)$ were dead. Twenty-nine patients $(27 \%)$ came under the general heading "status uncertain," including 10 suspect users. Those designated as "off drugs" (23\%)
TABLE IV-Evidence that 25 Patients were Off Drugs in April 1971

\begin{tabular}{|c|c|c|c|c|c|c|c|c|}
\hline $\begin{array}{l}\text { Seen N.A.R.I. } \\
\text { Seen other doctor } \\
\text { Evidence of Spelthorn } \\
\text { Evidence of relation } \\
\text { Change of life-style }\end{array}$ & $\begin{array}{lc}. & \ldots \\
\because & \cdots \\
\text { ne } & \text { Nursing } \\
\cdots & \ldots \\
\ldots & \ldots\end{array}$ & $\begin{array}{l}\ldots \\
\therefore \\
\text { Home } \\
\ldots\end{array}$ & $\begin{array}{l}\ldots \\
\cdots \\
\cdots \\
\cdots\end{array}$ & + & + & $\begin{array}{l}+ \\
+\end{array}$ & $\stackrel{+}{+}$ & + \\
\hline No. of patients & $\ldots$ & $\ldots$ & $\ldots$ & 7 & 5 & 5 & 5 & 3 \\
\hline
\end{tabular}

were patients for whom we had some corroborative evidence to that effect. The evidence available is listed in Table IV. It will be noted that social history is an important aspect of the assessment. We consider change of life-style, as evidenced by marriage (or perhaps separation, where the other partner remained drug dependent), bringing up of a family, change to regular employment, etc., as being probably incompatible with continued illicit opiate use. We have indirect data of this sort for eight patients and direct clinical confirmation (including repeated urine tests) as well as social history for the other 17 .

A discussion of the follow-up from first contact is contained in our previous paper (Chapple et al., 1972). Here we wish to clarify those findings by attempting a reconstruction of addict life history, beginning with the first notification to the Home Office.

\section{Follow-up from Notification}

The basis for this study is the fact that the first notification to the Home Office is one of the few objective milestones in the addict's history of opiate use. We feel that as the addict's report of his or her use of opiates is not only likely to be unreliable but also usually impossible to verify, the history of addiction needs to have an objective starting point. It can be argued that with a few exceptions first contact with treatment authorities represents an important step in the addict's involvement from the point of view of extent and regularity of drug use. It is unfortunate that with the present prescribing policy regular narcotic prescriptions may often be a clinic's only means of ensuring attendance by the early addict.

Twenty-two patients were excluded from this follow-up. Fifteen were foreign nationals, and hence the first date of notification in the U.K. did not represent their first contact with treatment authorities, and seven were excluded because their first seven years of drug use occurred before their initial contact with us (notified before 1958).

The seven-year follow-up is shown in Table V. Incomplete evidence for the seventh year on 17 patients (notified in 1965) means that the seventh year $(n=69)$ is a "construction" indicating only change in status of the remaining patients from the previous year.

The drug situation in Britain is a rapidly changing one, and yearly follow-ups of a cohort of patients will show changes corresponding to such chronological events as changes in legislation. In our follow-up from first contact there was, for example, a sustained increase in the number of patients using methadone $(6.5 \%$ to $18.5 \%$ ) and a decrease in those in hospital (from $11 \%$ to $4 \%$ ), corresponding chronologically with the opening of the Government treatment centres (follow-up years three and four).

TABLE v-Follow-up from Notification: "Life History" of British Non-therapeuticAddicts. Figures given are Percentages

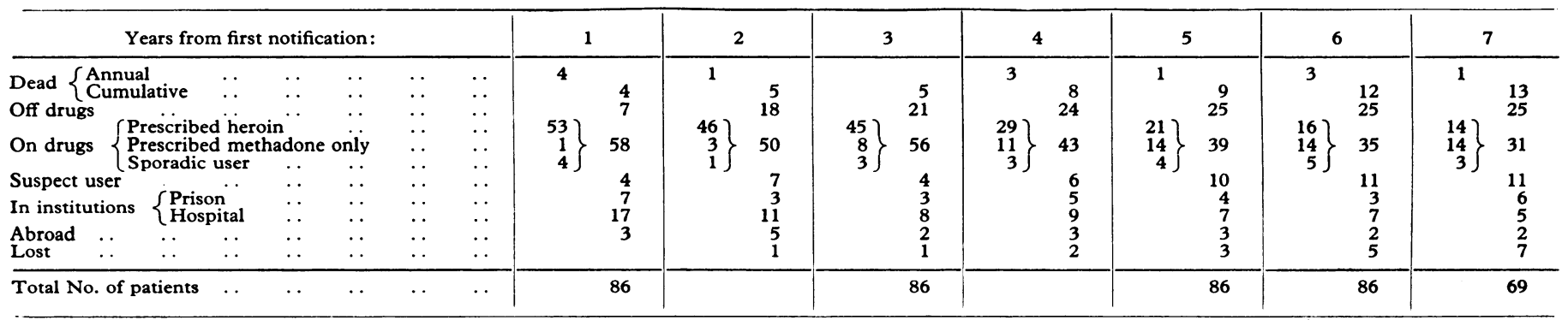


In the follow-up shown in Table $\mathrm{V}$ these chronological changes are less pronounced, though apparent. Nevertheless, other trends are present which cannot be ascribed to this factor and which we suggest are characteristic of the addiction pattern of our patients. The most obvious feature is that most patients who came off drugs $(18 \%)$ did so in the first two years after notification-that is, before they became stage 3 addicts-the proportion increasing by only $7 \%$ in the next five years. The figures for three to seven years, then, represent (by definition) a follow-up of chronic addicts, and it is seen that there was a small regular decrease (about $4-5 \%$ a year) in those on drugs. This is balanced by small increases in those dead, off drugs, suspect, or lost, all within the range $1-2 \%$ a year.

\section{Comparisons with Other Studies}

O'Donnell (1965) defined some of the features necessary in an adequate follow-up study of opiate users. Basically these amount to having a reliable classification system where the degree of evidence for a particular status definition is specified. Elsewhere (O'Donnell, 1969) he emphasized the need to minimize the proportion of those subjects classified as lost. The only American follow-up studies that appear to fulfil these criteria are those of Duvall et al. (1963), Vaillant (1966a, 1966b, 1966c, 1966d), and O'Donnell (1969). Despite rather wide differences in the characteristics of the subjects included it is interesting to note that their findings at five years were similar to ours. For in all four studies, of subjects known and alive at five years, $20-30 \%$ were off narcotics and $50-60 \%$ were still involved with drugs.

Vaillant's detailed 12-year follow-up of 100 consecutive male first admissions to Lexington in 1952-3 is the only one which bears close comparison with ours, in that length of drug usage before admission is specified. Vaillant's subjects were first addicted at a mean age of 23 years, on average two years before admission to Lexington. In Table VI the five-year findings from first contact are compared with the use of Vaillant's (1966) classification. The latter is similar to ours (Table V) although arrived at in different countries and independently.

There are only two notable differences. The proportion in institutions probably reflects the differences in legal and treatment practice between the U.S.A. in 1957 and Great Britain in 1969-70. The death rate difference needs further elucidation. Half of Vaillant's cases were Negroes. After 12 years the death rate from natural causes was 12:1 for white and Negro groups respectively (Vaillant, 1966c). Vaillant dismissed this as due to sampling error. Nevertheless, despite his claim to the contrary close scrutiny of the data given by Duvall et al. (1963) shows that there the death rate for white patients was more than double that of Negro patients. Thus we can surmise that the death rate of Vaillant's white subjects was probably more like that of the present cases. It is worth pointing out that sex differences are relevant here. Vaillant's 100 cases were all male. Duval et al. and O'Donnell both confirm our finding that although there are no sex differences as regards relapse or abstinence, male deaths from unnatural causes are much more frequent than female deaths. Our limited figures show 17 male deaths out of a total of 19, comparable with the 6 to 1 ratio observed by Gardner (1970).

Vaillant (1966b) also compared the characteristics of 50 chronic addicts admitted during 1952-3 with his 100 first admissions. The chronic addicts had been addicted for a mean period of over seven years. He noted that on every anniversary of addiction about $2 \%$ of chronic addicts became "permanently" abstinent and about $1 \%$ died or became chronically institutionalized-as we found in our follow-up from notification.

Vaillant's findings with regard to abstinence substantiate ours. Henderson (1970) indicated that Vaillant's was the first study to use social data to substantiate classification of addicts. Unfortunately Henderson's own large study of Canadian addicts used only indirect criteria for drug status, so that comparison is not possible. Nevertheless, he gave a very comprehensive critique of the methodology underlying Winick's (1964) theory of "maturing out." Vaillant (1966d) found, as we did, no convincing evidence of "burning out" in the mid-30 age range, and it seems that Winick's theory, although plausible, still lacks firm factual support.

There are no British follow-up studies sufficiently detailed to compare with ours direct. As regards social data, Mahon (1970) studied the case histories of 491 opiate addicts attending three Government clinics. His arrest data on 89 subjects were of the same order as those obtained by one of us (M.E.T., unpublished) on a sample of 305 subjects, which included the 108 cases. This study of the relation of criminality and addiction is nearing completion.

Bewley and Ben-Arie (1968) and Bewley et al. (1972) reported on two short-term follow-ups. The figures are shown in Table VII. Comparison is not really possible because Bewley's

TABLE VII-Short-term Follow-ups (One to Two Years) in the U.K. Figures given in Percentages

\begin{tabular}{|c|c|c|c|}
\hline $\begin{array}{l}\text { Author and date } \\
\text { of follow-up: }\end{array}$ & $\begin{array}{c}\text { Chapple et al. (1972) } \\
\text { April } 1966\end{array}$ & $\begin{array}{c}\text { Bewley and } \\
\text { Ben-Arie (1968) } \\
\text { January } 1968\end{array}$ & $\begin{array}{c}\text { Bewley et al. (1972) } \\
\text { April } 1970\end{array}$ \\
\hline $\begin{array}{l}\text { Dead } \\
\text { Prescribed opiates } \\
\text { In institutions ... } \\
\text { Abroad .. } \\
\text { Off drugs } \\
\text { Other outcomes }\end{array}$ & $\left.\begin{array}{l}11 \\
50 \\
15 \cdot 5 \\
4 \\
15 \cdot 5 \\
4\end{array}\right\}$ & $\begin{array}{r}13 \\
53 \\
14 \\
5 \\
15\end{array}$ & $\begin{array}{r}2 \\
52 \\
12 \\
2 \\
18 \\
14\end{array}$ \\
\hline No. of patients .. & 108 & 100 & 397 \\
\hline
\end{tabular}

classification of "not known to be using" or "other outcomes" is not sufficiently specific. We find more significant the fact that in his later study, with a younger population, the percentage of patients whose classification was dubious had doubled. Also Boyd et al. (1971), in a short-term follow-up of 78 young stage 1 addicts, found $13 \%$ not assessable and $18 \%$ suspected of illicit opiate use (having lapsed from notification).

\section{Discussion}

The "life-history" of addiction presented here spans at most seven years and involves fewer than 100 patients. Nevertheless, the findings are consistent with those of our previous paper. In terms of staging our figures show that about half of those classified as off drugs come into this category before qualifying as stage 3 addicts. Altogether $72 \%$ (18 of 25$)$ of those who had not relapsed to date were off opiates by the third year from an initial Home Office report. The use of an annual spot-check measure of drug status (including as it does, social evidence) appears to be justified when long-term trends are under consideration. Thus 23 out of 32 patients designated as off drugs during the seven years had remained drug-free for more than three years (equivalent to Vaillant's "good outcomes").

Although this study has definite limitations it was most encouraging to find many points in common between our and

TABLE VI-Comparison of Five-year Follow-up Findings. Figures are Percentages

\begin{tabular}{|c|c|c|c|c|c|c|c|c|c|c|c|c|}
\hline & & & & Dead & Well & Addicted & Marginal & $?$ & In Institutions & Abroad & Lost & $\begin{array}{l}\text { No. of } \\
\text { Patients }\end{array}$ \\
\hline $\begin{array}{l}\text { Vaillant (1966a) } \\
\text { Chapple et al. (1972) }\end{array}$ & $\therefore$ & $\because$ & $\begin{array}{l}\ldots \\
\cdots\end{array}$ & $\underset{11 \cdot 5}{6}$ & $\begin{array}{l}22 \\
24\end{array}$ & $\begin{array}{l}43 \\
36 \cdot 5\end{array}$ & $\begin{array}{l}3 \\
3\end{array}$ & $\begin{array}{r}8 \\
10\end{array}$ & $\begin{array}{r}15 \\
6\end{array}$ & $\overline{4}$ & $\begin{array}{l}3 \\
5\end{array}$ & $\begin{array}{l}100 \\
103^{*}\end{array}$ \\
\hline
\end{tabular}

Five patients died during first admission. 
American studies, despite the great differences in characteristics of the patients. It seems relevant that the study most closely resembling ours was also a follow-up study of addicts from their first contact with treatment authorities. Close examination of Vaillant's (1966a) tables shows that over half of those classified as well at the end of the 12-year study were in this category by the second year of follow-up. He also confirmed the poor outlook of chronic addicts.

We suggest that there may be a "fail-safe" period of two to three years after which the outlook for patients is poor. The implications for treatment are twofold. Firstly, we are in agreement with Gardner and Connell (1970) and Glatt (1969) that abstinence-orientated treatment is probably most appropriate for stages 1 and 2 addicts. Secondly, as a corollary, from an experience of oral methadone extending over several years we concur with Gardner and Connell regarding the need for caution in prescribing methadone by mouth. We would not consider its use with stages 1 or 2 addicts except sometimes in the form of a short dosage-reducing course. The figures of both Bewley et al. (1972) and Boyd et al. (1971), which show a higher proportion of patients whose exact drug status could not be ascertained on short-term follow-up, are also suggestive in this context. There are two possible reasons for this change-firstly, an increasing black market in adulterated, Chinese heroin and, secondly, that stages 1 and 2 addicts may be less consistently involved with opiates, which lends weight to our suggestions for treatment. The implications of this study for a narcotic-prescribing policy, we feel, deserve further investigation.

Finally, the need for a more extensive follow-up is evident. One of the present patients relapsed to regular opiate use after being opiate-free for six years. Also, Vaillant pointed out that only $28 \%$ of his group did not use barbiturates or alcohol to excess at one time or another. O'Donnell confirmed this, and although our data are incomplete we have firm evidence of alcohol abuse (Chapple, 1972) among several of our otherwise drug-free patients. It is disturbing to reflect that our "good outcomes" may cease to be regarded as a problem only because they have become submerged in a much larger section of the community who use either oral barbiturates or alcohol or both to excess. It is possible that the larger a particular drug problem the less likely it is that its very existence will be admitted and appropriate action taken.

Acknowledgement is made to the Home Office Drugs Branch for the use of their records; they have no responsibility whatsoever for any of the conclusions. Reprints may be obtained from Dr. P. A. L. Chapple.

\section{References}

Bewley, T. H. (1965). British Medical fournal, 2, 1284

Bewley, T. H., and Ben-Arie, O. (1968). British Medical fournal, $1,727$. Bewley, T. H., et al. (1972). International Symposium on Drug Abuse,

Boyd, P., et al. (1971). British Medical Fournal, 4, 604

Chapple, P. A. L. (1972). To be published.

Chapple, P. A. L., et al. (1972). British Fournal of Addiction, 67, 33

Drugs Branch, Home Office (1970). U.K. Statistics of Drug Addiction and Criminal Offences Involving Drugs. London, Drugs Branch, Home Office.

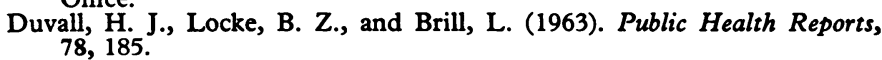

Gardner, R. (1970). Lancet, 2, 650

Gardner, R., and Connell, P. H. (1970). Lancet, 2, 455.

Glatt, M. M. (1969). British fournal of Addiction, 64, 165.

Henderson, I. (1970). An Exploration of the Natural History of Heroin Addiction. Vancouver, Narcotic Addiction Foundation of British Addiction.

Mahon, T. (1970). Doctoral Thesis, Florida State University.

Mahon, T. (1970). Doctoral Thesis, Florida State University.

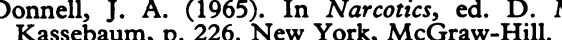

O'Donnell, J. A. (1969). Narcotic Addicts in Kentucky, Public Health Service Publication No. 1881. Washington, Public Health Service.

Vaillant, G. E. (1966a). American fournal of Psychiatry, 122, 727.

Vaillant, G. E. (1966b). New England fournal of Medicine, 275, 1282.

Vaillant, G. E. (1966c). Archives of General Psychiatry, 15, 599.

Vaillant, G. E. (1966d). American fournal of Psychiatry, 123, 573.

Winick, C. A. (1964). U.N. Bulletin on Narcotics, 18, 1.

\title{
Further Experience with Epigastric Pain Reproduction Test in Duodenal Ulceration
}

\author{
RICHARD J. EARLAM
}

British Medical fournal, 1972, 2, 683-685

\section{Summary}

Further evidence is presented that the epigastric pain of duodenal ulceration, situated between the rib margins and just below the xiphisternum, arises from the lower oesophagus.

One-hundred patients with duodenal ulceration were divided into those with epigastric pain (61) and those with pain in the upper abdomen but not in the epigastrium (39). Perfusion of $0.1 \mathrm{~N} \mathrm{HCl}$ into the lower oesophagus reproduced epigastric pain in 53 of the 61 with epigastric pain (mean $37 \mathrm{ml}$ ) but in none of the 39 without (mean $125 \mathrm{ml}$ ). All those who had been woken by epigastric pain at night in the previous four weeks had a positive test.

The London Hospital, London E.1

RICHARD J. EARLAM, M.CHIR., F.R.C.S., Consultant Surgeon
In five the test remained positive even though the acid was neutralized by a continuous perfusion of alkali just below the gastro-oesophageal junction. In another five $200 \mathrm{ml} \mathrm{O} 1 \mathrm{~N} \mathrm{HC1}$ instilled into the stomach for 21 minutes did not reproduce epigastric pain, even though $30 \mathrm{ml}$ perfused for three minutes into the lower oesophagus did.

\section{Introduction}

If weak hydrochloric acid is perfused into the lower oesophagus of patients with duodenal ulceration under accurate manometric control epigastric pain, indistinguishable from that normally suffered, can be reproduced (Earlam, 1970). When a patient had duodenal ulcer pain in sites other than the epigastrium the test was always negative. But not all those with epigastric pain had a positive test in the original study so further experiments have been evolved to establish whether epigastric pain really did arise from the lower oesophagus and why there was possibly an individual variation. The oesophageal origin of this type of pain would be likely if large amounts of intra- 